\title{
EL VUELO DE LA PALOMA: GÓNGORA, LORCA Y LA POESÍA HISPANO-ARÁBIGA
}

\author{
Jesús Ponce CÁrdenas \\ UnIVERSIDAD COMPLUTENSE DE MADRID
}

La celebración del octogésimo aniversario de la constitución del grupo del 27 está promoviendo a lo largo de estos últimos meses un interesante debate en torno a las aportaciones y los defectos que caracterizaron la boga neobarroca que se impuso en la España de los años veinte. El enjuiciamiento de aquellas brillantes creaciones y de los encomiables trabajos filológicos que fundaron el moderno gongorismo venía, en realidad, de algo más atrás. Tan necesaria valoración, fruto de un distanciamiento objetivo, respondía sin duda al juicioso intento de luchar contra determinadas inercias críticas, al ansia de superar un caudal de ideas preestablecidas. Desde su doble condición de poeta y filólogo, Andrés Sánchez Robayna ponía en aviso contra algunas actitudes derrotistas:

$\mathrm{Ni}$ es cierto que los poetas y críticos de la generación del 27 ofrecieran, en el plano filológico, una definitiva recuperación de la obra de Góngora (pese a sus notables contribuciones en esa área, muy en especial las del admirable Dámaso Alonso), ni es menos falso que esa obra quedara 
inscrita en los lenguajes líricos veintisietistas como signo identificador de la generación misma y como asunción modélica del influjo de Góngora en la lírica del siglo $\mathrm{XX}$, hasta el punto de invalidar como mimética, poco пиеva o poco original toda aproximación posterior a las lecturas llevadas a cabo por Diego o Alberti, Alonso o Guillén, Lorca o Cernuda. ${ }^{1}$

Con igual energía se expresaba en fechas más cercanas el profesor José Lara Garrido, al asumir con cuantiosos reparos la labor efectuada por Gerardo Diego y algún que otro secuaz del autor del Manual de espumas:

La actualización forzada por esta especie de filología poética tenía su contrapunto en acusadas limitaciones de intelección y explicación históricas. Las fallas de un ejercicio amateur y sin norte metodológico [...] lastró indefectiblemente el resolutivo alegato que daba carta de naturaleza en 1927 a la tradición gongórica. ${ }^{2}$

En verdad, la recuperación de la poesía gongorina (tanto desde la ladera creativa, como desde la filológica) debe considerarse a la luz de las tensiones propias de un complejo proceso histórico-estético en el que intervinieron gustos e intereses personales, desaconsejables prisas, estrategias de autopromoción, alegatos pro domo... Mas no es tiempo ahora de escudriñar el proceloso y apasionante panorama que emerge de los epistolarios y las tesis doctorales de algunos integrantes del grupo del $27 .{ }^{3}$ Desde un ámbito de estudio mucho más modesto, quisiéramos centrarnos aquí en dilucidar algunos interesantes matices de hibridación presentes en aquella tradición áurea donde se inscribe con radiantes ecos la poesía de Federico García Lorca. ${ }^{4}$

\footnotetext{
${ }^{1}$ Tomo la cita de la introducción del profesor canario a su Silva gongorina, Madrid, Cátedra, 1993, pp. 9-19 (p. 10).

${ }_{2}^{2}$ "La estela de la revolución gongorina. Relieves para una cartografía incompleta del gongorismo", en A. Soria Olmedo (ed.), Una densa polimorfía de belleza. Góngora y el Grupo del 27, Sevilla, Junta de Andalucía, 2007, pp. 121-168 (en especial, pp. 122-123). Resultan asimismo de obligada lectura otras valiosas páginas de J. Lara Garrido dedicadas a la elaboración de un "Nuevo escorzo para el Góngora del 27", Mercurio. Panorama de libros, 91 (Junio 2007), pp. 10-11.

${ }^{3}$ La complejidad de dicho trasfondo se comprende con una primera lectura del volumen cuidado por Gabriele Morelli: Gerardo Diego y el III centenario de Góngora (correspondencia inédita), Valencia, Pre-Textos, 2001. De suma importancia resulta asimismo la recién exhumada tesis guilleniana: Notas para una edición comentada de Góngora (eds. A. Piedra y J. Bravo, prólogo de J. M. Micó), Valladolid, Fundación Jorge Guillén-Universidad de Castilla-La Mancha, 2002.

${ }^{4}$ Recupero el marbete de un interesante ensayo de Francisco J. Díez de Revenga: La tradición áurea. Sobre la recepción del Siglo de Oro en poetas contemporáneos, Madrid, Biblioteca Nueva, 2003, pp. 93-139 (se localizan allí las aproximaciones parciales "Sobre Góngora y el 27: recapitulación" y "García Lorca en 1927: neotradicionalismo, neobarroquismo").
} 
Desde que pronunciara en el Ateneo su famosa conferencia en torno a La imagen poética de Luis de Góngora, el nombre de Federico García Lorca quedaría asociado a la imponente figura del genio barroco. ${ }^{5}$ El conocido y muy personal texto crítico del escritor granadino serviría, a partir de entonces, para trazar ocasionales paralelos entre la poética del maestro secentista y su moderno admirador. Bajo el estímulo de las afirmaciones recogidas en dicha conferencia, los hispanistas se lanzaban con denuedo a la "caza de imágenes" gongorinas que pudieron inspirar a Lorca. Como podrá verse a continuación, no vamos a seguir ahora ese tipo de enfoque, ni hemos de centrarnos tampoco en el apasionante fragmento conservado de la Soledad insegura. ${ }^{6}$ En cierto modo, nuestra investigación se acoge a una línea que distinguió con característica maestría el decano de los estudios gongorinos, ya que en fechas muy tempranas afirmaba Dámaso Alonso:

Una nota del arte de Góngora es su andalucismo. La literatura novísima $[. .$.$] ofrece dos interesantes y radicalmente diferenciadas$ manifestaciones de poesía andaluza. Andalucismo oriental, bravío de sierra y bandoleros, el de Federico García Lorca; occidental, de mar y de salinares, el de Rafael Alberti. ${ }^{7}$

A la luz de esta sintética revelación sobre el poso meridional compartido por Luis de Góngora y Federico García Lorca, nuestro interés se centrará exclusivamente en uno de los poemas redactados a finales de 1935 y principios de 1936, los celebérrimos sonetos amorosos encaminados a Rafael Rodríguez Rapún. ${ }^{8}$

\footnotetext{
${ }^{5}$ Como aproximación global a las lecturas y la relación del poeta granadino con el autor secentista, pueden verse los trabajos de Joseph Velasco, "Góngora et Lorca", Criticón, 6 (1979), pp. 46-83 y Francesco Guazzelli, “Lorca legge Góngora”, en G. Poggi (ed.), Da Góngora a Góngora, Pisa, Edizioni ETS, 1997, pp. 287-297.

${ }^{6}$ Para un primer contraste de la imitatio gongorina practicada por Alberti y Lorca, puede consultarse el artículo de Javier Pérez Bazo, "Las Soledades gongorinas de Rafael Alberti y Federico García Lorca, o la imitación ejemplar", Criticón, 74 (1998), pp. 125-154.

7 "Góngora y la literatura contemporánea", en Estudios y ensayos gongorinos, Madrid, Gredos, 1982, pp. 518-566 (p. 559). Como es sabido, Dámaso Alonso redactaba estas páginas en 1927 y vieron la luz por vez primera en 1932.

${ }^{8}$ Asumiendo cierta distancia, ha defendido una lectura de los sonetos ajena a la clave homosexual Epicteto Díaz (en "El amor oscuro en los sonetos de García Lorca”, Draco, 2 (1990), pp. 35-49). Una postura más matizada ofrece Víctor Infantes en "Lo oscuro de los Sonetos del amor oscuro de Federico García Lorca", en Gabriele Morelli (ed.), Federico García Lorca: saggi critici nel cinquantenario della morte, Fasano, Schena Editore, 1988, pp. 57-88.
} 
Como bien ha subrayado la crítica, los meses previos a la trágica muerte del escritor suponen para éste el amanecer de un nuevo rumbo estético, marcado por la necesidad del retorno al clasicismo. En ese preciso marco se inscribe el texto del que hemos de ocuparnos ahora, una composición que podría surgir de la contaminación de estilemas barrocos y de algún otro elemento aún no bien precisado, cuyo remoto origen se liga en cierta forma a la pervivencia del epigrama helenístico o a la imaginería arábigo-andaluza. Leamos, pues, los endecasílabos del Soneto gongorino en que el poeta manda a su amor una paloma:

Este pichón del Turia que te mando, de dulces ojos y de blanca pluma, sobre laurel de Grecia vierte y suma llama lenta de amor do estoy parando.

Su cándida virtud, su cuello blando, en limo doble de caliente espuma, con un temblor de escarcha, perla y bruma la ausencia de tu boca está marcando.

Pasa la mano sobre su blancura y verás qué nevada melodía esparce en copos sobre tu hermosura.

Así mi corazón de noche y día, preso en la cárcel del amor oscura llora sin verte su melancolía. ${ }^{9}$

Redactado a la manera de una 'tarjeta lírica' que había de acompañar el envío de una paloma como presente, el soneto se inserta en unas coordenadas bien precisas de la tradición clásica. Como es sabido, la retórica votiva de los Anathematiká coleccionados en el libro VI de la Antología Griega, fue reelaborada por el mayor de los epigramatistas latinos en dos amplias secciones de su monumental colección de poemas breves. Así, los Xénia (Regalos para los amigos) y los Apophóreta (Obsequios para los invitados) conformaron los libros XIII y XIV de los Epigramas de Marcial. ${ }^{10}$ En cada liber se ofrece un amplísimo

\footnotetext{
${ }^{9}$ Federico García Lorca, Obras completas (ed. A. del Hoyo), Madrid, Aguilar, 1989, t. I, p. 946. Para las variantes del manuscrito, puede verse la reproducción fotográfica del poema en Patrick Paul Garlinger, "Federico García Lorca's Sonetos del amor oscuro", Bulletin of Spanish Studies, LXXIX (2002), pp. $709-730$ (p. 720).

${ }^{10}$ Para el examen de la tradición epigramática hispana en relación con sus modelos antiguos resulta capital un estudio reciente de Sagrario López Poza, “La difusión y recepción de la
} 
abanico de versos que en su día acompañaron a los regalos donados por el escritor; dichos dísticos portaban algún mensaje (reflexivo, suavemente burlón, o amistoso sin más) para el destinatario. ${ }^{11}$ Por cuanto ahora nos atañe, hemos de precisar que el cantor de Bílbilis había recogido allí numerosas composiciones concebidas para presentar el obsequio de diferentes aves; la variedad de las mismas es tal que llega a comprender nada menos que veintiséis especies. ${ }^{12}$ De tan abigarrada colección ornitológica, nos interesa traer aquí a la memoria los versos consagrados a las Columbinae (Palomas) y los Palumbi (Palomas torcaces):

Ne violes teneras periuro dente columbas,

tradita si Gnidiae sunt tibi sacra deae.

'Con sacrílego diente no mancilles a las tiernas palomas,

si te han sido comunicados los rituales de la diosa de Gnido'.

Inguina torquati tardant hebetantque palumbi:

non edat hanc volucrem qui cupit esse salax.

'Las palomas torcaces reprimen y embotan sus impulsos carnales: que no coma tal ave quien desee ser lascivo' ${ }^{13}$

Tal como atestigua la pareja de dísticos redactada por Marcial, desde la Antigüedad clásica el regalo de palomas estaba asociado a un contexto amoroso y sensual, ya que la cándida ave era el animal emblemático de la diosa Venus.

Pese a que casi podamos descartar de plano un conocimiento directo de los epigramas latinos por parte de Lorca, ${ }^{14}$ no deja de resultar interesante que éste recordara tal linaje de aves cuando ponderaba la quintaesenciada sensualidad que caracteriza la poesía de Góngora: “La Fábula de Polifemo y Galatea es un poema de erotismo puesto en sus últimos términos. Se puede

Antología griega en el Siglo de Oro", en B. López Bueno (coord.), En torno al canon: aproximaciones y estrategias, Sevilla, Universidad de Sevilla, 2005, pp. 15-67.

${ }^{11}$ De manera modélica, Vicente Cristóbal López ha abordado el estudio de la pervivencia del bilbilitano en nuestras letras: "Marcial en la literatura española", Actas del Simposio sobre Marco Valerio Marcial, Zaragoza, Diputación de Zaragoza, 1987, t. II, pp. 149-210.

${ }^{12}$ La extensísima serie se localiza en lib. XIII, eps. 45, 51-53, 61-78 y lib. XIV, eps. 73-76, 217. El elenco íntegro comprende pollos, tordos, patos, tórtolas, francolines, gallinas cebadas, capones [dos veces], perdices, palomas, palomas torcaces, oropéndolas, cotorras, pavos reales, flamencos, faisanes, gallinas de guinea, gansos, grullas, becadas, cisnes, porfiriones, loro, cuervo, ruiseñor, picaza, halcón.

${ }_{13}$ Martial, Epigrams (ed. W. C. A. Ker), London-Cambridge, William Heinemann-Harvard University Press, 1968, p. 414. Para la traducción, sigo el texto de A. Ramírez de Verger y J. Fernández Valverde: Marcial, Epigramas, Madrid, Gredos, 1997, vol. II, p. 339.

${ }^{14}$ Aunque cite al bilbilitano en su Teoría y juego del duende: "En España tiene el duende un campo sin límites sobre los cuerpos de las bailarinas de Cádiz, elogiadas por Marcial" (Prosa, Madrid, Alianza, 1969, p. 185). 
decir que tiene una sexualidad floral [...]. ¿Cuándo se ha descrito un beso de una manera tan armoniosa, tan natural y sin pecado como lo describe nuestro poeta en el Polifemo? No a las palomas concedió Cupido / juntar de sus dos picos los rubies, / cuando al clavel el joven atrevido / las dos hojas le chupa carmesies". La naturaleza venérea o cupidinosa de esas mismas aves nuevamente se subrayaba en otro pasaje de la conferencia: "llama a la paloma, quitándole con razón su adjetivo de cándida, el ave lasciva de la cipria diosa".${ }^{15}$ En suma, las admirativas aseveraciones que el autor de la Soledad insegura recogiera en su famoso texto crítico acaso cohonesten la hipótesis de una asociación clásica entre el eros sensual y la paloma, un vínculo conceptual que pudo llegar hasta él a través de la mediación gongorina.

A la luz de los venerables precedentes señalados, quizá no resulte exagerado afirmar que el soneto lorquiano muestra un parentesco remoto con un microgénero inscrito en el orbe del epigrama: los Xénia o 'Regalos para los amigos'. Mas la fortuna de tan curioso género no se limitó al mundo helenístico, ya que estos singulares poemas de los dones perduraron más allá de la cronología antigua, hasta el punto que no resulta difícil hallar ejemplos del mundo medieval ya asociados claramente a un contexto amoroso. En efecto, se han conservado pequeños textos líricos concebidos para acompañar el envío de toda clase de obsequios que el poeta galán ofrendara a la dama: una rosa, un limón, unas cerezas, un retrato, una red, unas cuentas, un anillo, un cordón, unos guantes... ${ }^{16}$ Como el lector bien puede imaginar, también la ofrenda de un ave daría ocasión a algún interesante poema cancioneril. Acaso convenga evocar ahora el testimonio de los versos cuatrocentistas de Florencia Pinar, quien compuso una melancólica Canción a unas perdices que le enviaron vivas:
D'estas aves su nación
es cantar con alegría
$y$ de vellas en prisión
siento yo grave pasión
sin sentir nadie la mía.
Ellas lloran que se vieron
sin temor de ser cativas,
y a quien eran más esquivas

\footnotetext{
${ }^{15}$ Federico García Lorca, Prosa, Madrid, Alianza, 1969, pp. 120-121 y p. 118.

16 Álvaro Alonso, Poesía amorosa y realidad cotidiana: del Cancionero General a la lírica italianista, London, University of London, 2001, pp. 9-11, 40-49, 52-54.
} 


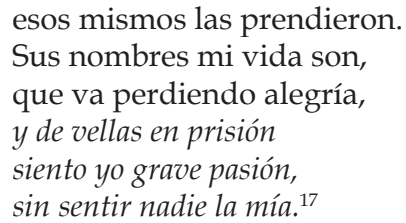

Esa misma boga, refinada y galante, del poema regalo dirigido a la amada tampoco fue ajena a los grandes autores áureos, desde los albores del Renacimiento hasta las postrimerías del Barroco: Marullo hacía llegar violetas y lirios a su adorada Neera ("Has violas atque haec tibi candida mano lilia mitto"), Jorge de Montemayor redactaba unos versos a una dama "enviándole un vaso de mármol muy blanco", Vicente Espinel unos octosílabos para acompañar el envío de una fruta (la "lima"), Francisco de Medrano un soneto admonitorio que advierte a Galatina junto a una flor ("Esta que te consagro fresca rosa"), Antonio de Paredes tejía asimismo una oda para acompañar un ramillete de claveles, violetas, jazmines y rosas ("Estas, Éfire bella, suaves flores")... Si se presta un poco de atención al incipit de varias composiciones de este microgénero, lograríamos reconocer una primera marca retórica del mismo: el uso de la deixis de cercanía que sirve para notar verbalmente la inmediatez del regalo ("d'estas aves", "has violas", , esta [...] rosa", "estas [...] flores").$^{18}$ Intuimos que la huella de ese artificio retórico resulta apreciable en la apertura del soneto lorquiano: "este pichón". Sin duda, otro elemento que desempeña una función axial en esta gavilla de poemas regalo será la naturaleza del propio objeto donado, ya que en muchos de ellos la ofrenda misma encierra también el mensaje. Por espigar un caso que presenta una muy remota afinidad con la pieza lorquiana, cabría recordar el célebre soneto VIII de los Rerum Vulgarium Fragmenta. Se trata de una pieza de ocasión encaminada a un destinatario histórico, unos versos con los que Petrarca acompañaba un regalo:

\footnotetext{
${ }^{17}$ Poesía de Cancionero (ed. A. Alonso), Madrid, Cátedra, 1995, p. 378. Alan Deyermond comenta estos octosílabos en "El gusano y la perdiz: reflexiones sobre la poesía de Florencia Pinar", Poesía de Cancionero del Siglo XV, Valencia, Universidad de Valencia, 2007, pp. 259-265. Puede confrontarse la alusividad del texto con el desgarro de una décima secentista del conde de Villamediana (A una dama que le envió una perdiz): “Niña, pues en papo chico / no cabe chica mitad, / con perdiz almorzad, / porque tiene pluma y pico. / Si mentalmente os fornico, / no me lo podéis negar, / que Amor sabe penetrar / hoy, primer día del año, / mil puertas con un engaño, / mil llaves con un mirar" (Poesía impresa completa, Madrid, Cátedra, 1990, p. 929).

${ }^{18}$ De hecho, la retórica de la contigüidad ostenta un origen milenario: el deíctico inicial aparecía ya entre los epigramas anathematiká del libro VI de la Antología Griega (como aquel de Simónides [VI, 2] donde se consagra un arma a Atenea tras la guerra, cuyos versos principian "Este arco").
} 


\begin{abstract}
A pie' de' colli ove la bella vesta prese de le terrene membra pria la donna che colui ch'a te ne'nvia spesso dal somno lagrimando desta,

libere in pace passavam per questa vita mortal, ch'ogni animal desia, senza sospetto di trovar fra via cosa ch'al nostr'andar fosse molesta.

Ma del misero stato ove noi semo condotte da la vita altra serena un sol conforto, et de la morte, avemo: che vendetta è di lui ch'a ciò ne mena, lo qual in forza altrui presso a l'extremo riman legato con maggior catena. ${ }^{19}$
\end{abstract}

El octavo soneto del Canzoniere presenta un interesante perfil como poema ofrenda, ya que es la única composición en toda la raccolta petrarquesca donde el yo lírico enamorado y doliente no sustenta la enunciación poética. Como revela Marco Santagata, estos endecasílabos acompañaban una ofrenda cinegética dirigida probablemente al protector del humanista, Giovanni Colonna. El discurso poético se ponía así en boca de unas aves capturadas que probablemente deben identificarse como palomas ("che si tratti di colombe può essere avvalorato, oltre che dal genere femminile ['libere', 'condotte'], dal fatto che il testo è un mosaico di tessere lessicali e di situazioni desunte dal V canto dell'Inferno"). ${ }^{20}$ Más allá de la naturaleza coincidente de los dones (un blanco pichón, un conjunto de palomas), las divergencias con la bellísima pieza lorquiana resultan, pues, tan cuantiosas como indudables, aunque ahora no podamos dejar pasar por alto el significativo contacto que establece el cierre de ambos poemas: el autor (que engloba en Petrarca la figura del cazador "lui ch'a ciò ne mena") se halla en la misma penosa situación que las aves prisioneras ("in forza altrui presso a l'extremo / riman legato con maggior catena"), condenado a crudelísimo cautiverio. ${ }^{21}$

\footnotetext{
${ }^{19}$ Canzoniere (ed. Marco Santagata), Milano, Mondadori, 1997, p. 41.

${ }^{20}$ Marco Santagata, ed. cit., pp. 41-42.

${ }^{21}$ Jane Whetnall ha estudiado "las coincidencias de tema y contexto" entre el soneto petrarquesco y la cancioncilla de Florencia Pinar en un sugerente trabajo: "Las transformaciones de Petrarca en cuatro poetas de cancionero: Santillana, Carvajales, Cartagena y Florencia Pinar", Cancionero General, 4 (2006), pp. 81-108 (en especial, pp. 101-107). Agradezco a Álvaro Alonso que me haya hecho notar, con generosidad suma, la trascendencia de dicho artículo.
} 
Una vez apuntado el primer rasgo significativo que entraña la capacidad alusiva de las ofrendas, se impone la necesidad de dilucidar las irisadas valencias simbólicas de la paloma en el soneto lorquiano. Como es bien sabido, la paloma durante la época clásica tenía connotaciones afines a las mostradas por la perdiz en la Edad Media, ya que ambas especies ornitológicas se ligaban al mundo de la sensualidad y la lascivia. ${ }^{22}$ Al aire de esta reflexión, la búsqueda de posibles paralelos con ejemplos autorizados del naciente Humanismo llevaría a Jorge Guillén a sostener que el poema "mantiene viva la gran corriente de Petrarca. En su Canzoniere LXXXI se pregunta: Qual grazia, qual amore o qual destino / mi darà penne in guisa di colomba? El estado amoroso se concreta en imagen. Pues así en el soneto gongorino el poeta manda a su amor una paloma". ${ }^{23}$ La exquisitez y oportunidad de la cita resultan indudables, mas no existe nada más lejano de los derroteros espirituales del Canzoniere (y su bellísima traducción del séptimo verso del Psalmo LIV: "Quis dabit mihi pennas sicut columbae, et volabo, et requiescam?") que los sensuales endecasílabos de la pieza lorquiana.

Lejos de todo ese caudal clásico y renacentista, es probable que los derroteros melancólicos del Soneto gongorino nacieran realmente de las sugestiones de una colección poética que el genio de Granada había hecho suya poco tiempo atrás, me refiero a la antología de Poemas arábigo-andaluces publicada por Emilio García Gómez en 1930. ${ }^{24}$ Entre las páginas de tan deslumbrante volumen, aparecen unos versos de Abulhasan Alí Abenhisn, secretario de Almotámid (rey de Sevilla entre 1069 y 1091), que llevan por título El pichón:

Nada me turbó más que un pichón que zureaba sobre una rama, entre la isla y el río.

Era su collar de alfóncigo, de lapislázuli

su pechuga, tornasolado su cuello,

castaño el dorso y el extremo de las plumas del ala.

\footnotetext{
${ }^{22} \mathrm{Mi}$ radio de interés se halla lejos de las reflexiones post-modernas de Ángel Sahuquillo, "Las palomas de Gil-Albert y de Lorca", apartado 2.17 de Federico García Lorca y la cultura de la homosexualidad masculina, Alicante, Diputación de alicante, 1991, pp. 161-165.

${ }^{23} \mathrm{El}$ breve comentario del soneto lorquiano redactado por Guillén puede leerse en el Epílogo que éste redactara para los Sonetos del amor oscuro. Poemas de amor y erotismo. Inéditos de madurez (ed. Javier Ruiz-Portella), Barcelona, Ediciones Áltera, 1995, pp. 39-40.

${ }^{24}$ Entre agosto de 1931 y agosto de 1934 Lorca había redactado trabajosamente las personalísimas recreaciones de la poesía islámica que conforman el Diván del Tamarit. Los dos hipotextos principales que le sirvieron de norte en dicha aventura estética fueron las Poesías asiáticas del conde de Noroña y los citados Poemas arábigo andaluces.
} 
Hacía girar sobre el rubí de su pupila párpados de perla y orillaba sus párpados una línea de oro. Negra era la aguda punta de su pico, como el cabo de un cálamo de plata mojado en tinta.

Se recostaba en la rama del arac como en un trono, escondiendo la garganta en el repliegue del ala.

Mas, al ver correr mis lágrimas, le asustó mi llanto e irguiéndose sobre la verde rama, desplegó sus alas y las batió en su vuelo, llevándose mi corazón. ¿A dónde? No lo sé. ${ }^{25}$

Casi a vuela pluma, puedenotarse cómolos versos de Abenhisn comparten con los endecasílabos de Lorca varios rasgos similares: la demorada recreación en la hermosura del ave (cuello, ojos, pico, dorso y pluma), el arrebatador zureo (nevada melodía) del pichón, la retórica de las lágrimas de un locutor poético entristecido, la imagen final del corazón (preso o robado)... El interesante poema hispano-musulmán permitiría distinguir cómo la paloma no sólo estaría ligada a la esfera voluptuosa, sino que también puede remitir a la aegritudo amoris. De hecho, esa última imagen del ave en la lírica hispano-árabe es relativamente frecuente, como nos hace pensar el cordobés Omar Ben Omar, que también plañía la ausencia en el poema La amada: "Recordando su talle, gimo de amor, / como las palomas que lloran sobre las ramas" ${ }^{26}$ Llegados a este punto, resulta inevitable el recuerdo de la figura del célebre esteta e inspirado cantor Ibn Hazm de Córdoba (994-1063). Como es sabido éste obtuvo la fama con el tratado El collar de la paloma, apasionante volumen filográfico redactado no lejos del Turia, ya que la misiva de un amigo almeriense alcanzaba al poeta y erudito musulmán hacia el año 1022 en la roca de Játiva. Como todos recuerdan, dicha carta le exhortaba a redactar un ensayo sobre la naturaleza del amor. En el sugestivo prosímetro del escritor arábigo-andaluz se localizan anécdotas sazonadas con destellos líricos, promovidos por la inserción de breves poemas. Así, por espigar una pequeña muestra, la paloma aparece en una de tales composiciones asociada a la mensajería de amor:

Yo conozco dos amantes que usaban como mensajero una paloma amaestrada, en cuyas alas ataban las cartas. Sobre este asunto he dicho en un poema: "Noé la eligió y no burló las esperanzas / que puso en ella,

\footnotetext{
${ }^{25}$ Emilio García Gómez (trad.), Poemas arábigo andaluces, Madrid, Editorial Plutarco, 1930, pp. 42-43.

${ }^{26}$ Ibidem, p. 76.
} 
porque le trajo buenas nuevas. / Yo también le confiaré las cartas que te escriba. / Mira, pues: ¡las cartas van en las plumas de un ave!" ${ }^{27}$

En el poemita de Ibn Hazm la referencia explícita a un pasaje del Antiguo Testamento identifica a la paloma como portadora de un mensaje de amor que anuncia paz y concordia. Mas la espera del yo lírico enamorado a menudo se hace dolorosa. A la exaltación de la unión amorosa y a los padecimientos de la ausencia se dedican asimismo hermosas páginas, que veladamente van esbozando la doctrina amorosa del Collar, que se sustenta en una raíz oculta heredada de la tradición helenística: el concepto de la melancolía de amor. ${ }^{28}$

Para delimitar la confluencia de orígenes del soneto lorquiano, resulta muy reveladora una afirmación de D. Alonso, quien (con característica perspicacia) destacaba en un párrafo revelador las afinidades existentes entre ciertas imágenes gongorinas y el estilo de la lírica hispano-árabe:

La poesía árabe andaluza gusta - lo mismo que Góngora - de incluir dentro de un poema, en unos pocos versos, una rápida descripción de un objeto, condensada en una nítida y recortada imagen. Viven así ante nosotros una intensificada vida mínimos seres de la realidad: la azucena, la nuez, la berenjena, el membrillo, el pichón, el dedal, la naranja, el brasero, las tortugas de una alberca, el lunar, el gallo, la alcachofa, la botella negra. Los temas muchas veces coinciden con los de Góngora; cuando no, los gongorinos podían sin dificultad haber sido árabes y los árabes, gongorinos. ${ }^{29}$

Según los parámetros establecidos por esta intuición damasiana, en los versos de Lorca que ahora nos ocupan podría distinguirse un doble legado que se sustenta en una estética afín: entre los renglones del soneto ofrenda el poso gongorino iría de la mano de la escondida herencia arábigo-andaluza. Una vez revelado el secreto vuelo de la paloma, llega el momento de esbozar una aproximación formal a la pieza. La arquitectura textual del soneto remite a la clásica oposición entre cuartetos y tercetos, según un esquema tripartito: - el locutor poético pondera la belleza del animal regalado (1-8), - exhorta al

\footnotetext{
${ }^{27}$ El collar de la paloma. Tratado sobre el Amor y los Amantes de Ibn Hazm de Córdoba (trad. E. García Gómez), Madrid, Sociedad de Estudios y Publicaciones, 1952, p. 121.

${ }^{28}$ Ramón Mujica Pinilla, El collar de la paloma del alma. Amor sagrado y amor profano en la enseñanza de Ibn Hazm y de Ibn Arabi, Madrid, Hiperión, 1990, p. 50.

${ }^{29}$ La cita pertenece al bello artículo sobre "Poesía arábigo-andaluza y poesía gongorina", recogido en Estudios y ensayos gongorinos, Madrid, Gredos, 1982, pp. 31-65 (pp. 52-53). La cursiva es mía.
} 
amado para que acaricie la suave ofrenda (9-11), -exalta el dolor que despierta en él la ausencia (12-14). En las cuatro estrofas se verifica muy sutilmente una alternancia: entre el yo (cuarteto primero) y el tú (cuarteto segundo), entre el tú (terceto primero) y el yo (terceto segundo). Creo que dicha alternancia conlleva un mensaje implícito en cada uno de los elementos referidos por las cuatro estrofas. En el primer cuarteto, la "paloma" que "vierte" la amorosa "llama" sobre "laurel" configura el mensaje de un yo lírico consciente de su labor como escritor (lo subraya el título mismo: "el poeta manda a su amor una paloma"). El ígneo "pichón del Turia" encarna la arrasadora pasión de ese locutor ausente, el "laurel de Grecia" condensa los valores simbólicos de la perpetuación a través de la escritura, de la tópica eternización a través de la poesía (exegi monumentum aere perennius). ${ }^{30}$ Con la estrofa siguiente se verifica el salto a la esfera del amado. La sentida belleza de la paloma, cuya descripción indirecta abunda en sensaciones táctiles ("blando", "caliente", "temblor") y visuales ("cándida", "espuma", "escarcha", " perla", "bruma"), suscitan en la imaginativa del poeta la sensualidad distante del objeto de su deseo, pues todas subrayan "la ausencia" de su "boca". En el primer terceto, el yo lírico insta al amado para que acaricie a la paloma, pues su tacto le revelará (con efectos sinestésicos) la blanca música de su plumaje o el rumor plácido de su zureo. El terceto final casi reviste la forma de un epifonema, con el abrupto regreso de la enunciación al universo sufriente del locutor poético: la ausencia es una lóbrega "cárcel de amor" donde sólo queda espacio para llorar en "melancolía".

Desde el punto de vista de la elaboración del material lingüístico, por senderos estéticos afines, el soneto de Lorca plantea, como la Araceli de Alberti, un nuevo ejemplo de virtuosismo lírico. El poético tour de force se sustenta nuevamente sobre el sinatroísmo que conforma una extensa cadena de imágenes enlazadas por la albura refulgente: "blanca pluma”, "cándida virtud", "espuma", "escarcha", "perla", "bruma", "blancura", "nevada", "copos". Acaso no esté de más recordar ahora los versos recogidos por el poeta pintor del Puerto de Santa María en Cal y canto:

No si de arcángel triste, ya nevados los copos sobre ti de sus dos velas.

\footnotetext{
${ }^{30}$ Cierta crítica ha querido ver aquí una alusión sesgada al mito de Apolo y Dafne. Según dicha clave, Andrew A. Anderson estimaba que la figura de Apolo estaría ligada al homoerotismo de la entera colección de sonetos: Lorca's late poetry: a critical study, Leeds, Francis Cairns Publications, 1990, pp. 362-372 (p. 364).
} 
Sí de serios jazmines, por estelas de ojos dulces, celestes, resbalados.

No si de cisnes, sobre ti cuajados, del cristal exprimidas carabelas. Sí de luna sin habla cuando vuelas, si de mármoles mudos, deshelados.

Ara del cielo, dime de qué eres, si de pluma de arcángel y jazmines, si de líquido mármol de alba y pluma.

De marfil naces y de marfil mueres, confinada y florida de jardines lacustres, de dorada y verde espuma. ${ }^{31}$

Al recorrer estos endecasílabos, estaríamos tentados de afirmar que la quintaesenciada elegancia de la dama-cisne cantada por Alberti se contrapone al candor natural de la paloma lorquiana. Frente al complejísimo poema del gaditano, no encontramos en este otro soneto gongorino un claro homenaje a las piruetas sintácticas del creador de las Soledades. Apenas algún artificio como la hipálage sencilla ("cándida virtud", "nevada melodía”), la presencia delatinismos ("cándida"), la rima de elementos plásticos ("pluma/espuma") o el epíteto de valor metafórico (Góngora usaba a menudo como variación del blanco el mismo participio: "nevada invidia sus nevadas plumas", "púrpura nevada", "nevada huella") recuerdan tenuemente el estilo del genial racionero. Quizá en esa misma factura sutil, podría destacarse la relativa abundancia de bimembraciones (vv. 2, $5,6)$, donde el poeta contemporáneo va alternando la disposición paralelística (v. 2) y la quiástica (vv. 5, 6). ${ }^{32}$ A zaga de estas consideraciones, cabe también notar la presencia de una serie de voces que no pertenecen al léxico selecto de la obra gongorina ("bruma", "escarcha”, "limo").

\footnotetext{
${ }^{31}$ R. Alberti, Obras completas. Poesía (ed. J. Siles), Barcelona, Seix Barral, 2003, vol. I, p. 397. Quizá debido a una errata de la edición príncipe (1929), se ha perpetuado la lectura de "si" como arranque de los vv. 3 y 7. Creo que la lógica interna de la contraposición exige que leamos "sí". Para un examen más detenido de dicha pieza, remito al artículo: "Con dos sonetos de Alberti: teselas gongorinas para un aniversario", en Luis García Montero (coord.), "Ayer y Hoy. Lecturas del 27", en Insula, 732 (diciembre 2007), pp. 12-14.

${ }^{32}$ Pese a que Candelas Newton relaciona el poema con el soneto 375 (1623) de Góngora (“Los paisajes del amor: iconos centrales en los Sonetos de Lorca", Anales de la literatura española contemporánea, 11 (1986), pp. 143-159 [p. 149]), no veo clara una identificación del poema moderno con un hipotexto gongorino.
} 
Los juegos con distintos eslabones de la tradición poética no se limitan únicamente a cuanto ya hemos apuntado, sino que también resulta posible individuar en el soneto ecos aislados de San Juan de la Cruz. Así ocurre en sintagmas del tenor de "preso en la cárcel del amor oscura" (v. 13) o "llama lenta de amor" (v. 4), que evocan de lejos algún célebre pasaje de las Canciones del alma en la intima comunicación de unión de amor de Dios, como la inicial "llama de amor viva" (v. 1) o el cerrado espacio de "las profundas cavernas del sentido, / que estaba obscuro y ciego" (vv. 15-16). ${ }^{33}$

Al tratar de identificar los espejeantes juegos que practica Lorca en su reelaboración de la tradición literaria, hemos evitado cuidadosamente engolfarnos en los procelosos mares de la interpretación psicoanalítica, que tantas resonancias fálicas podría ver en el poema. Nuestro propósito era muy otro. Mas no deja de sorprender entre los partidarios de estas "lecturas en clave" una ausencia significativa, pues al hablar de imágenes ligadas a un contexto sensual, ¿cómo no llegan siquiera a mencionar aquella tradición humanista que había atribuido valencias lascivas al passer de Lesbia cantado por Catulo? ${ }^{34}$

En verdad, el soneto lorquiano presenta un rico ejercicio de contaminación de fuentes y géneros, una asombrosa síntesis de tradiciones y estilos: desde la configuración epigramática del soneto-regalo, al simbolismo amoroso de la paloma hispano-arábiga, sin olvidar los sintagmas de ascendencia sanjuanista o los artificios sintácticos de sabor clásico, que ostentan levísimas reminiscencias gongorinas. Tras haber indagado en la vertiginosa cadena lírica que, de manera difusa, se vislumbra a través de los renglones del exquisito poema, llega el momento de cerrar esta apresurada relección de la discutida pieza lorquiana. En definitiva, si - según el aserto gongorino - " plumas no son malas / para lisonjear a un dios con alas", tanto Cupido como el destinatario sin nombre del soneto podían darse por satisfechos con la negra pluma que trazó la escritura, con el tibio plumón blanco que el amor distante sostendría ensimismado entre sus palmas.

\footnotetext{
${ }^{33}$ Amplía y contrasta esta información Juan Matas Caballero en un exhaustivo artículo: “Federico García Lorca frente a la tradición literaria: voz y eco de San Juan de la Cruz en los Sonetos del amor oscuro", Contextos, XVII-XVIII (1999-2000), pp. 361-384.

${ }^{34}$ Ese mismo guiño burlesco de ascendencia humanística llegaba, de hecho, hasta la Tisbe gongorina, donde puede leerse: "Ofrecióle su regazo / y yo le ofrezco en su muslo / desplumadas las delicias / del pájaro de Catulo" (vv. 449-452). Para un comentario amplio del tema puede leerse el estudio"Sobre el epilio burlesco: aspectos léxicos y estrategias discursivas del erotismo en siete poetas barrocos", en E. Lacarra Lanz, Asimetrías genéricas. 'Ojos hay que de lagañas se enamoran', Bilbao, Universidad del País Vasco, 2007, pp. 195-239.
} 


\section{Coda final}

Esta pequeña tesela neobarroca que hemos tratado de explicar a la luz de la tradición literaria proporciona de manera indirecta alguna información sobre la lectura del genial racionero que llevó a cabo uno de los miembros más relevantes del grupo del 27. Composiciones breves como Araceli, Amaranta o el Soneto gongorino en que el poeta manda a su amor una paloma, prueban que tanto Lorca como Alberti no se limitaron a captar las esencias de las obras mayores del vate cordobés, sino que supieron identificar en él al maestro (inalcanzable) de una forma cerrada y difícil como el soneto. A mi entender, los tres sonetos modernos también identifican dos rasgos principales de la obra secentista del genio innovador, pues tácitamente reconocen a Luis de Góngora como poeta del eros y de la naturaleza. Esa doble coincidencia (junto al arrebatador poderío de la imagen) también la supo distinguir por esos años una figura tan versátil como Ramón Gómez de la Serna, que delimitaba la creatividad gongorina en una sugestiva prosa poética:

Góngora recoge esa evaporación de metáforas que se verifica en los atardeceres de España y en los aledaños de las poblaciones españoles, la cantidad de polen de distintas flores auténticas, flores de abajo, flores de lo profundo de la tierra y con ese polen da tan gran fuerza a sus versos [...]. Góngora fue maestro de realidades, destilador de realidades [...], quiso retener humos, perfumes y - sobre todo - esas diminutas estrellas que, como jazmines de los cielos, cuelgan sobre la verja de la tierra. ${ }^{35}$

En definitiva, los dos grandes representantes de una renovación que inaugurabalatrayectoriamás brillanteenlalírica españoladelsigloXXproporcionan un inmejorable "ejemplo de relación equilibrada entre vanguardia y tradición" ${ }^{36}$ Parafraseando el conocido aforismo lorquiano, la poesía de Góngora hay que leerla con los cinco sentidos, estudiarla laboriosamente $y$, tras haberla delibado en sosiego, amarla como a un prodigio perfecto de bellezas. Probablemente, desde la temprana altura de la década de los 20 y hasta su muerte, Rafael Alberti y Federico García Lorca supieron hacerlo (leer, estudiar, amar) como nadie.

\footnotetext{
35 "Góngora el cordobés", artículo publicado en el número de junio (1927) de la Gaceta Literaria y reimpreso ahora por G. Morelli en el volumen Gerardo Diego y el III Centenario de Góngora (Correspondencia inédita), Valencia, Pre-Textos, 2001, pp. 207 y 209.

${ }^{36}$ L. García Montero, La palabra de Ícaro. Estudios literarios sobre García Lorca y Alberti, Granada, Universidad de Granada, 1996, p. 96.
} 


\section{BibLIOGRAFÍA}

Alberti, Rafael, Obras completas. Poesía (ed. J. Siles), Barcelona, Seix Barral, 2003, vol. I.

Alonso, Álvaro, Poesía amorosa y realidad cotidiana: del Cancionero General a la lírica italianista, London, University of London, 2001.

Alonso, DÁmAso, "Poesía arábigo-andaluza y poesía gongorina", en Estudios y ensayos gongorinos, Madrid, Gredos, 1982 (3. ${ }^{\mathrm{a}}$ ed.), pp. 31-65.

"Góngora y la literatura contemporánea", en Estudios y ensayos gongorinos, Madrid, Gredos, 1982 (3. ${ }^{a}$ ed.), pp. 518-566.

ANDERSON, ANDREW A., Lorca's late poetry: a critical study, Leeds, Francis Cairns Publications, 1990.

CRISTóbal López, Vicente, "Marcial en la literatura española”, Actas del Simposio sobre Marco Valerio Marcial, Zaragoza, Diputación de Zaragoza, 1987, t. II, pp. 149-210.

Díaz, Epicteto, "El amor oscuro en los sonetos de García Lorca", Draco, 2 (1990), pp. $35-49$.

Díez de Revenga, Francisco J., La tradición áurea. Sobre la recepción del Siglo de Oro en poetas contemporáneos, Madrid, Biblioteca Nueva, 2003.

Garlinger, Patrick Paul, "Federico García Lorca's Sonetos del amor oscuro", Bulletin of Spanish Studies, LXXIX (2002), pp. 709-730.

García Gómez, Emilio (trad.), Poemas arábigo andaluces, Madrid, Editorial Plutarco, 1930.

García Lorca, Federico, Prosa, Madrid, Alianza, 1969.

, Sonetos del amor oscuro. Poemas de amor y erotismo. Inéditos de madurez (ed. Javier Ruiz-Portella), Barcelona, Ediciones Áltera, 1995.

Guazzelli, Francesco, “Lorca legge Góngora”, en G. Poggi (ed.), Da Góngora a Góngora, Pisa, Edizioni ETS, 1997, pp. 287-297.

Guillén, Jorge, Notas para una edición comentada de Góngora (eds. A. Piedra y J. Bravo, prólogo de J. M. Micó), Valladolid, Fundación Jorge Guillén-Universidad de Castilla-La Mancha, 2002.

INFANTES, Víctor, “Lo oscuro de los Sonetos del amor oscuro de Federico García Lorca”, en Gabriele Morelli (ed.), Federico García Lorca: saggi critici nel cinquantenario della morte, Fasano, Schena Editore, 1988, pp. 57-88.

LARA GARRIDO, JOSÉ, "La estela de la revolución gongorina. Relieves para una cartografía incompleta del gongorismo", en A. Soria Olmedo (ed.), Una densa polimorfía de belleza. Góngora y el Grupo del 27, Sevilla, Junta de Andalucía, 2007, pp. 121-168.

, "Nuevo escorzo para el Góngora del 27", Mercurio. Panorama de libros, 91 (Junio 2007), pp. 10-11.

López Poza, Sagrario, "La difusión y recepción de la Antología griega en el Siglo de Oro", en B. López Bueno (coord.), En torno al canon: aproximaciones y estrategias, Sevilla, Universidad de Sevilla, 2005, pp. 15-67

Matas Caballero, Juan, “Federico García Lorca frente a la tradición literaria: voz y eco de San Juan de la Cruz en los Sonetos del amor oscuro", Contextos, XVII-XVIII (1999-2000), pp. 361-384. 
Morelli, Gabriele (ed.), Gerardo Diego y el III centenario de Góngora (correspondencia inédita), Valencia, Pre-Textos, 2001.

Mujica Pinilla, Ramón, El collar de la paloma del alma. Amor sagrado y amor profano en la enseñanza de Ibn Hazm y de Ibn Arabi, Madrid, Hiperión, 1990.

Newton, CANDEla, "Los paisajes del amor: iconos centrales en los Sonetos de Lorca", Anales de la literatura española contemporánea, 11 (1986), pp. 143-159.

Pérez BAZo, JAVIER, “Las Soledades gongorinas de Rafael Alberti y Federico García Lorca, o la imitación ejemplar", Criticón, 74 (1998), pp. 125-154.

Ponce Cárdenas, Jesús, "Sobre el epilio burlesco: aspectos léxicos y estrategias discursivas del erotismo en siete poetas barrocos", en E. Lacarra Lanz, Asimetrías genéricas. 'Ojos hay que de lagañas se enamoran', Bilbao, Universidad del País Vasco, 2007, pp. 195-239.

, "Con dos sonetos de Alberti: teselas gongorinas para un aniversario", en Luis García Montero (coord.), “Ayer y Hoy. Lecturas del 27”, en Ínsula, 732 (diciembre 2007), pp. 12-14.

SAhuquillo, Ángel, Federico García Lorca y la cultura de la homosexualidad masculina, Alicante, Diputación de alicante, 1991.

SÁnchez Robayna, AndRés, Silva gongorina, Madrid, Cátedra, 1993.

Velasco, Joseph, “Góngora et Lorca”, Criticón, 6 (1979), pp. 46-83.

Whetnall, JANE, “Las transformaciones de Petrarca en cuatro poetas de cancionero: Santillana, Carvajales, Cartagena y Florencia Pinar", Cancionero General, 4 (2006), pp. 81-108. 